\title{
ECONOMIA E CULTURA NO CIRCUITO DAS FESTAS POPULARES BRASILEIRAS
}

\author{
Edson Farias*
}

\begin{abstract}
Resumo: O propósito deste artigo é sublinhar alguns aspectos que caracterizam a convergência entre cultura e economia de símbolos e espaços, a partir da montagem de um circuito de grandes festivais atravessando diferentes regiões brasileiras. Observa-se como a formação deste circuito de eventos compõe um quadro mais amplo do estabelecimento da estrutura social urbano-industrial e de serviços, no interior da qual o lazer e o entretenimento interferem no plano dos valores e das expressões, com efeitos sobre a resignificação de domínios de memórias. Por outro lado, é também considerado como tais remanejamentos simbólicos são fundamentais à própria dinâmica deste comércio de bens de diversão, à medida que articulam afetos, estimas e estilos de vida aos esquemas da rentabilidade do capital.
\end{abstract}

Palavras-chaves: festas populares, economia de símbolos e espaços, práticas lúdico-artísticas.

\section{Introdução}

A imensidão cósmica era surpreendida, em 1997, com a propagação dos acordes melódicos e da percussão do samba Coisinha do Pai. Assinada pelos compositores Jorge Aragão, Almir Guineto e Luis Carlos, a canção ecoou na voz da cantora Beth Carvalho para despertar uma sonda espacial norte-americana em Marte, por indicação de uma integrante da equipe de engenharia da NASA - a brasileira Jaqueline Lira. Negligenciando esta informação,

\footnotetext{
* Edson Farias é professor do Programa de Pós-Graduação em Ciências Sociais da Universidade Federal da Bahia; pesquisador do Grupo Cultura, Memória e Desenvolvimento.
}

Recebido em 5 ago. 2005; aprovado em 10 dez. 2005. 
no Brasil, não foram poucos os que se apressaram em classificar como sendo aquele o nascimento do primeiro "samba intragaláctico". Enfim, prenhes de orgulho, a conclusão era certeira entre muitos círculos de nativos nacionais: a cultura popular brasileira tomara de assalto todo o universo, universalizara-se! ${ }^{1}$ Descontados os arroubos nacionalistas e o tom um tanto pitoresco e anedótico de algumas das interpretações, o fato chama a atenção para um processo já com profundo enraizamento tanto nos domínios de memórias quanto nas sociabilidades no país. A saber, a convergência entre a produção de bens culturais lúdico-artísticos reconhecidos como populares e os sistemas técnicos e empresariais de disseminação de informações e com o comércio de símbolos. Afinal, o caminho que percorre a canção até chegar ao planeta vizinho é pavimentado pelas conexões das áreas da elaboração e circulação de significados com abrangência sobre estimas e sentimentos no desenho de identidades coletivas e individuais com os mercados profissionalizados de produção e consumo de bens fonográficos, mas, incluindo, também, semelhantes mediações envolvendo a indústria e os círculos de distribuição de peças audiovisuais. Além, ainda, dos enlaces cada vez mais evidenciados entre operadoras turísticas, agências de viagens, ramos dos transportes, da hotelaria e da gastronomia e núcleos artesanais e semiprofissionalizados de manifestação artística e desempenhos voltados à diversão.

O problema enfocado neste artigo, portanto, diz respeito à relevância adquirida pelo entrosamento de informação com cultura. O interesse recai sobre os espaços reunindo as práticas lúdicas e/ou religiosas, justamente no rastro das transformações nos suportes de expressão dos símbolos, no instante em que são inseridos em circuitos mais cosmopolitas, por meio da sintonia entre políticas públicas e a atuação da iniciativa privada empresarial. Observa-se que, desde aí, a recomposição das lembranças depositadas nos sistemas das práticas lúdico-artísticas populares têm ido em direção a diferentes nichos de mercado. Situação já bastante consolidada, principalmente, em setores com adiantada profissionalização, à maneira de atividades como a música popular e o futebol, ou seja, os principais ícones da brasilidade. Para o nosso argumento, a redefinição dessas práticas significativas 
ocorre na alteração das instâncias que as legitima e visibiliza: cada vez menos o Estado e as instituições vinculadas apenas aos poderes locais, porque as redes ampliadas de interdependências em que se inserem dispõem os diversos indivíduos e grupos realizadores às pressões e atravessamentos político-econômicos e culturais variados, embora concatenados aos ramos comerciais do entretenimentoturismo. Entendemos que algo assim se dá sob a mesma esteira da expansão da malha urbana, mais precisamente no momento em que os estilos de vida urbanos dão margem à adoção por entre vastas facções sociais de fórmulas de objetivação de atitudes nas quais são priorizados os critérios de apresentação a amplas e heterogêneas audiências.

Nesta redefinição das disposições de expressão, dar-se-ia o ajuste de determinadas expressões e atividades voltadas aos serviços de lazer com o padrão de acumulação do capital notabilizado pelo grau intensificado no amálgama entre instâncias financeiras e as organizações empresariais voltados ao comércio de informação, em consórcio com a infra-estrutura de comunicação de base eletrônica. Assim, acredito, desenha-se a teia coligando núcleos formais e informais jurídico-institucionais de graus e naturezas distintas, mas orientadas para o lucro obtido por intermédio da prestação de serviços monetarizados de diversão, integrando a dimensão da modernização capitalista no país. Modernização que permitiu a inserção dos meios mecânicos de reprodução da audioalidade e da visualidade na consolidação de um parque industrial da cultura e contíguo à emergência e aprofundamento de um mercado do simbólico e dos ramos responsáveis pelas atividades turísticas.

A opção analítica se detém no circuito de sociabilidades de diversão deflagrado na montagem de festas populares espalhadas por áreas distintas do Brasil. O encontro entre cultura e economia capitalista, nessas festas, tem contrapartida no agenciamento de muitos meios de vida e de expressão referidos a domínios de memórias étnicos, de classe e etários semelhantemente variados. Além de descrever algumas das características desse circuito, portanto, o propósito é sublinhar como são tecidas as alianças entre algumas 
dessas singularidades étnico-históricas e as determinações de uma lógica do capital definida pela capacidade de se flexibilizar e, com isto, articular símbolos e espaços à sua dinâmica de auto-rentabilidade.

\section{Tradicional e moderno nas condições urbano-industriais e de serviços}

$\mathrm{Na}$ América Latina e, principalmente, no Brasil, pelo menos desde os folcloristas, na virada do século XIX para o XX, curiosamente as discussões sobre os folguedos e festas populares portam a seguinte ambigüidade, derivada da maneira como um e outro foram inseridos no debate a respeito do dueto nação e modernidade. Referidos às franjas sociais, ambas as expressões da "cultura do povo" estariam no interstício do presente com o vestuto, do bárbaro com o civilizado, mas integrando a narrativa sobre as mestiçagens que confere profundidade histórica, define uma tradição brasileira pelo princípio da transigência e torna possível uma totalização nacional mediada pela narrativa sobre a "vocação carnavalesca" de, ao promover o diálogo, tornar planos da experiência social antagônicas “complementares e necessários para o todo" (Matta,1985, p. 89). ${ }^{2}$

Ao longo do último século, a mesma dubiedade conheceu alguns impasses em virtude da própria expansão dos conglomerados metropolitanos no país, portando as instituições da modernidade de cuja influência se traduziu em alterações formidáveis no conjunto da estrutura social e do plano simbólico, com repercussões sobre as dimensões cognitivas, expressivas e comunicacionais. Façamos uma síntese dessas mudanças. Nesse período, emergiu um amplo e potente sistema produtor e consumidor de mercadorias, articulado internacionalmente, com uma intrigante base urbano-industrial e de serviços, possuidora de características muito peculiares em seus muitos aspectos, se comparadas às congêneres européias e mesmo norte-americanas (Faria, 1991, p. 102), incidindo, assim, sobre os modos de relacionamento entre os grupos e sobre as suas formações simbólicas, na contrapartida das definitivas transformações dinamizadas na economia brasileira, as quais vieram no caudal do 
implemento de atitudes modernizadoras por parte do Estado central. Sobremaneira favorecida, a base urbana tornou-se sede de um parque industrial incentivado seja pela política de substituição de importações, seja pela consolidação dos setores produtivos de bens de consumo duráveis e, posteriormente, dos bens intermediários e de capital, com o advento do governo militar. Desde 1940, contudo, a lógica industrialista ativa os entrelaçamentos na formação de um mercado nacional. A otimização na utilização dos recursos e equipamentos é soldada à dinâmica do processo de consumo de mercadorias. E ambos são conectados ao setor terciário da economia, no qual os serviços, a formulação intelectual e a veiculação de valores dispõem as bases materiais e simbólicas sobre as quais toda estrutura social organizarse-á. O espaço da dimensão urbana assume o centro do novo contexto nacional (Santos, 1993, p. 27).

O tema da cultura infla desde então, porque nele se inscreve a seguinte problemática: como cimentar simbolicamente esta sociedademercado nacional? Mediante o aparato tecnológico de processamento da informação, seria uma resposta parcial. Ela se complementa constatando que a qualidade dos símbolos é engendrada pelo imperativo de um tipo de comunicação capacitada a cruzar a diversidade de territórios simbólicos dispersos sobre a geopolítica nacional. Ou seja, passa a estar em jogo a formação de modelos identitários de amplo alcance a serem relacionados no espaço-tempo abstrato da sociedade. Vislumbra-se a formação de espécie de "memória cibernética", agenciada pelas instituições da comunicação aninhadas na indústria cultural. Essa memória opera o que deve ser lembrado ou esquecido segundo as contingências do presente, mas sua composição vai demandar a escolha de elementos armazenáveis que lhe sejam compatíveis, em termos da lógica informacional de simulação de consensos temporários, da adequação entre os suportes materiais de expressão e da potencialidade de instrumentalizar signos no circuito do consumo. Enfim, elementos simbólicos capacitados a circular em órbitas cosmopolitas, logo não fechados em universos étnicos, raciais, regionais ou mesmo nacionais fechados em seus limites. 
O outro lado da tendência à cosmopolitização de determinadas expressões corresponde às alterações morfológicas no espaço sociopolítico do País, em meio aos remanejamentos vinculados à primazia adquirida pela estrutura urbano-industrial e de serviços. Em conjunto com as elevadas taxas de crescimento demográfico vegetativo, a expansão do sistema urbano é favorecida pelo aumento do fluxo migratório, deslocando para ele, no curso de três décadas, mais de 30 milhões de pessoas de um campo cada vez mais secundário ante a supremacia da indústria, cujo impulso gerou em torno de 20 milhões de empregos no período. Com efeito, entre 1960 e 1980, a população urbana salta dos 18 para os 80 milhões, representando no início da década passada $68 \%$ dos habitantes do País. Este reordenamento significou entre nós impactos redimensionais sobre toda a divisão social do trabalho, suas estruturas funcionais e as ecologias culturais. O sistema urbano sobrepõe-se ao rural e, no interior do primeiro, as aglomerações metropolitanas tomam as rédeas dessa ambiência socioeconômica e simbólica, com a hegemonia do conglomerado centralizado nas metrópoles do Rio de Janeiro e de São Paulo (Faria, 1991, p. 103). Vale dizer que os novos rumos tomados pela sociedade brasileira formataram-na unificada em seu conjunto, mas diversificada, complexa e segmentada em sua estrutura prenhe de desigualdades sociais (p.105). O caráter das sociabilidades, observa ainda Vilmar Faria, sofre impressionantes ajustes, principalmente com a redefinição dos comportamentos ideais parametrados pelos valores hedonistas das novas parcelas da "classe média urbana consumidora", personagem imprescindível nessa trama urbano-industrial e de serviços. Mais que isso. A ampliação dos serviços de crédito ao consumidor e do sistema comercial de comunicação, calcada no mercado publicitário, permite que a propensão ao consumo de bens veiculados pelo mercado irrompa no campo das subjetividades, sintonizado agora com o aceleramento da subsunção dos modos de experiência individual e coletiva ao intercâmbio viabilizado pelo dinheiro.

Milton Santos (1993), também ocupado do mesmo período na história da urbanização brasileira, enxerga nesse o momento de expansão do "meio técnico-científico" no contexto geopolítico 
nacional. Para isso, diz, foi necessária a formação do que chama de uma "tecnoesfera", isto é, uma esfera definida pela competência baseada nos critérios da racionalidade científica e da eficiência tecnológica, mobilizada por engrenagens especializadas de agentes empenhados no emprego de alto grau numérico de informações analíticas e que as fazem circular por uma rede de canais interligando o espaço do País. Esta esfera, de acordo ainda com o geógrafo, é capaz de regular a economia e o território nacional independente das bases regionais, mas vinculada à socialização capitalista em escala mundial. Atribui a mesma importância à emersão de uma outra esfera voltada para o discurso do objeto, isto é, do seu desejo, do seu uso; esfera movida então por um vetor de racionalização da vontade individual, construindo uma homologia entre esta e a estrutura social do consumo. E mais uma vez, a instância da cultura moderna surge em sua conclusão como elo mediador de ambas as esferas (Santos (1993, p. 45-47). A problemática vincula-se à conformação dos atores sociais ao estatuto da sociedade de consumo, denominado de "ideal de conformidade" por Baudrillard (1979, p. 78). Nos seus termos, o valor de uso e a necessidade são perpassados desde o seu íntimo pela lógica do esquema da troca mercantil e da hierarquia dos significados legítimos que espiritualizam os objetos. Aescolha individual obedece assim aos parâmetros dos estilos de vida que, a um só tempo, segmentam a sociedade, porém simultaneamente também consistem em vias articuladoras. A dinâmica do consumo, ativada nesse nicho mercadológico, estabelece outras funções à organização e expressão da cultura.

Por outro lado, desde a década de 1990, o arranjo urbanoindustrial e de serviços na sua fase tardia, que ganha contornos sobre o espaço do Estado-nação brasileiro, igualmente compreende remanejamentos nos esquemas profissionais e penetra de modo agudo a própria conformação do mundo do trabalho. A indústria responde agora a menos de $13 \%$ da mão-de-obra empregada no setor formal, em razão da inversão da prioridade da produção do mercado interno para o mercado externo. Devido à pressão dos graus exacerbados de competitividade em nível global, o setor manufatureiro efetivou a eliminação de um milhão de empregos, entre 1980 e 1990 (Pochmann, 
2000, p. 55-56). Na contrapartida, a categoria de serviços ascende em igual período. Acompanhando uma tendência já em andamento nas economias capitalistas centrais, o setor de serviços que, em 1940, abrigava 20,05\% dos trabalhadores, passou a deter $59,5 \%$ na última década de noventa. O re-direcionamento de parcelas tão consideráveis do conjunto de trabalhadores para o setor de serviços teve por faceta a inserção da mão-de-obra na dimensão informal da economia, seja em razão dos percalços fiscais do Estado nacional, seja devido às novas exigências de flexibilização estrutural à regulação do capital na atualidade. De acordo com o IBGE (2002), durante os anos 90 o trabalho informal aumentou em $22 \%$ e os números de trabalhadores sem carteira assinada elevaram-se em $27 \%$. Nesse movimento, enquanto o mercado formal encolhe de $56 \%$ para $44 \%$, entre 1985 e 1998, o mercado informal absorve crescentemente força de trabalho, indo de $44 \%$ para $54 \%$ na mesma época. Se, portanto, dos 72 milhões de brasileiros empregados em 1999, apenas 26 milhões possuíam carteira assinada; na outra ponta do processo, $70 \%$ dos postos de trabalho criados foram no mercado informal.

À luz do quadro macro-estrutural descrito, é possível inferir a reordenação da categoria do popular promovida nessas circunstâncias socioeconômica e cultural, as quais são oxigenadas pelos novos ingredientes de modernização. Mecanismos estes conjugados ao avanço do processo social e civilizador moderno no Brasil, na maneira como este contribuiu para as alternativas de integração sociossimbólicas no País. Justamente porque a aludida caracterização do sistema urbano-industrial e de serviços brasileiro como "complexo e intrigante" coloca, no plano da cultura, os ajustes entre as sociabilidades e o impacto da socialização capitalista. Principalmente chama a atenção para o incremento tanto da rede monetária quanto dos circuitos de produção e consumo de bens culturais, dinamizados em torno das mídias comerciais e das atividades de lazer concertadas no campo do entretenimento-turismo. Portanto, o rastro a ser seguido neste artigo é a articulação entre novos agentes e instituições com elementos simbólicos re-significados na montagem e dinâmica do circuito de grandes festivais populares conectando diferentes regiões 
brasileiras. Pois o horizonte destas festas é sobremaneira o presente da sociedade, na qual o tema da recreação é resolvido por uma especialização funcional das práticas e dos sentidos nela produzidos e a inserção no mercado de bens de diversão dos patrimônios étnicohistóricos dos diversos conjuntos espaciais. Logo, no rastro destas alterações, mostra-se equivocada a pretensa incompatibilidade entre tradição das festas populares e modernidade. ${ }^{3}$ Em meio ao enlace entre cultura e economia, ao adquirirem relevância, vários festejos brasileiros despontam em determinadas pautas de desenvolvimento socioeconômico e são ressalvados enquanto fatores de modernização local e regional, em contraposição à imagem do "atraso".

A conexão de matrizes culturais, a princípio reconhecidas como folclóricas e tradicionais, com o entretenimento nesse circuito enseja a peculiaridade institucional das festas populares regionais enquanto festivais de diversão e lazer. Tessituras de significados em que estão entretidas experiências coloniais, posteriormente acomodadas às condições do Império e do período republicano, muitos folguedos e comemorações hoje identificados ao gênio popular compreendem domínios de memória onde se entretêm lembranças luso-católicas e igualmente africanas e ameríndias (Tinhorão, 2000). Os fundos mnemônicos são também compostos por outras interpenetrações culturais e são visíveis nas expressões à maneira dos traços italianos, britânicos e franceses nas folias carnavalescas e no ciclo junino (Cascudo, 2000, p. 114-116, 230-232 e 249-250; Côrtes, 2000). A mesma dinâmica de mescla repercute, hoje, no interior dos espaços festivos no momento em que os quadros de valores que definem as práticas enquanto lúdico-artísticas populares conhecem a reatualização dos seus significados na integração com aqueles mercados relativos aos ramos do lazer - gastronômico, de hospedagem e dos fluxos de transportes de passageiros, entre outros. Portanto, as festasespetáculo populares brasileiras compreendem acontecimentos que compõem agora um circuito de eventos-espetáculo cosmopolitas. Situações definidas em razão do forte apelo mercantil das atividades neles desenvolvidas, as quais estão voltadas para a prestação de serviços de diversão e turismo e se situam nos canais dos fluxos das 
redes midiáticas, pelos quais símbolos são insumos e mercadorias, a um só tempo. Neste âmbito estão amalgamadas expressão e produção culturais; profissionalismo e brincadeira.

Se o circuito de sociabilidades festivas corresponde à teia composta de situações de ócio em que a forma de convivência é referida pelo sentido lúdico que articula e circunscreve a diversidade de grupos nelas presentes, logo a recursividade a esse sentido condiciona a heterogeneidade de interesses, motivações e conhecimentos implicados nas condutas e expressões de indivíduos. Impõe-se então como a moldura na distribuição das práticas cujo somatório está na composição das respectivas ambiências das festas populares espalhadas pelas regiões brasileiras e cada vez mais ressaltadas nos roteiros turísticos como paisagens de lazer e diversão e nos programas de desenvolvimento socioeconômico pelas suas potencialidades de gerar renda e oportunidades de trabalho. É natural que a situação crie impasses tanto no plano teórico quanto no político, diante da tarefa de conceituar tais eventos enquanto expressões da cultura popular. A vigência deste circuito e sua sintonia com prerrogativas econômicas estão na contramão de algumas convicções a respeito das festas em uma condição em que prevalece a indústria, o mercado, as indústrias culturais, o comércio de diversões, entre outras instituições da modernidade.

Segundo toda uma tradição interpretativa que poderíamos nomear de romântico-folclorista, ${ }^{4}$ a feição de espetáculo adquirida por algumas das festividades introduziria um apelo à aparência que seria incongruente com as idéias de comunhão e reciprocidade intrínsecas à noção de festa, considerando-se para isso três elementos. Por um lado, a secular divisão social do trabalho, marcada pela assimetria entre os que fazem e os que apenas contemplam. De outro, a individualização dos agentes seria básica à profissionalização e, por conseqüência, estaria na contramão de qualquer ideal comunitário, na medida em que a convergência de meios e instrumentos na perseguição de fins deliberaria contrariamente ao anonimato das atitudes. Ainda, interferiria a mistificação da mercadoria capitalista, isto é, o primado do fascínio na exposição para 
consumidores (pagantes anônimos) do estético preponderaria sobre o desinteresse da ação pública espontânea. Com isto, opõem-se civilização e popular e o último compreenderia a "alteridade" em relação ao artificialismo autocontido, predominante nas formas de vida urbano-industrial. Enquanto uma pressão social exercida desde as áreas hegemônicas da dominação burguesa capitalista, a propensão para o espetáculo desviaria os modos populares de expressão lúdicoestética daquela unidade que resultaria da reciprocidade afetiva compartilhada por membros de uma coletividade circunscrita em limites étnicos e embebida dos conhecimentos intergeracionalmente acumulados. Sabendo estar o fundamento desta coletividade em determinada profundidade histórica, unidade a qual o lúdico da festa celebraria a espontânea solidariedade dos pares, quando "industrializadas" as expressões populares seriam reduzidas a peças funcionais da ampliação dos lucros empresariais, ao estar submetida ao engate entre tecnologia de reprodução e aportes financeiros (Rodrigues, 1984, p. 89; Tinhorão, 2001, p. 179-185).

Por outro lado, denuncia-se a adição do cálculo abstrato como o condicionante de uma racionalidade formal no seio da brincadeira; a estilização das condutas estaria na contramão do dispêndio de energias vitais, dissolvendo as características dionisíacas das festas coletivas. No célebre texto de Festas e Civilizações, o antropólogo francês Jean Duvignaud, atento às diferentes aparições da experiência festiva nas sociedades humanas, advoga que a festa "(...) quebra o encadeamento de acontecimentos que a ideologia européia nos apresenta como lógico e insuperável". Nesse sentido, os acontecimentos dessa natureza se inscreveriam em uma outra epistemologia, sensível à "nossa vida psíquica em sua totalidade que nenhuma ideologia pode ocultar" e, logo, na comprovação de que "a vida coletiva é realizada com o imprevisível e o inelutável e que a experiência comum faz romper em fragmentos, no tempo e no espaço, as belas construções unitárias, estruturais ou funcionais" (Duvignaud, 1978, p. 25). A seu ver, sobretudo em se tratando do Brasil e do conjunto da América Latina, a festa potencializaria dispositivo capaz de destronar a "epistemologia dominante", adepta de uma concepção de mundo calcada no empenho de instrumentalizar, no 
cálculo e no lucro: "A festa não é, em verdade, o exercício irracional com que a queriam rotular apenas porque não correspondia às categorias mentais de um mundo paralisado pela idéia de funcionalidade ou de rentabilidade. Afinal de contas, conforme dizia Hegel, se a realidade é irracional, muito bem, devemos nesse caso inventar uma conceituação irracional" (p. 25). No todo da sua excursão histórica e etnográfica, Duvignaud encontra nas muitas situações festivas vinculadas a tão diversas civilizações algo de (subversivamente) ancestral e incongruente com a almejada estabilidade, prevista no moderno projeto de domínio racional da natureza obediente à epistemologia lhe correlata; a saber, àquela de uma propensão intelectual ávida por homogeneizar a multiplicidade agonística da vida humana. Tratando-se, então, de uma "coordenação da destruição" (p. 67), na contramão do ímpeto voltado à imposição da unidade, as festas inclinariam a humanidade para um soçobrar lancinante mas restaurador.

Prevalece nessas interpretações socioantropológicas a crença de que determinados legados culturais dispostos nas memórias de grupos situados em áreas distantes do dinamismo industrial lhes tornariam refratários às mudanças seculares. Ao contrário, na confluência entre ócio e negócio, cada vez mais em tal circuito de sociabilidades festivas se acoplam tradições lúdico-artísticas populares às transformações modernizadoras ocorridas na sociedade-nação. Nesses termos, os quadros de valores e as práticas significantes e modos de agir e pensar a elas referidas em específicos nichos étnicohistóricos, enfim, as matrizes culturais, não comparecem à maneira de um fator conservador. Ao contrário, distinguem-se como elemento estruturante da racionalização social de áreas a princípio alheias ao impulso desenvolvimentista da modernidade, tornando-se fator de geração de riqueza e incremento da divisão das atividades compatibilizadas com a lógica monetária e a reprodução do capital (Hermet, 2002, p. 19-20), ainda que a distribuição dos montantes que resultam seja apropriada de maneira assimétrica. À luz desta tendência, diria que a montagem do circuito de sociabilidades festivas está associada à integração do espaço nacional mediante a 
interferência tanto dos artefatos técnico-científicos quanto dos ditames da monetarização. Algo posto na contrapartida do andamento da racionalização econômico-capitalista das relações sociais e da circunscrição de um território onde a lógica da produção e consumo da mercadoria atravessa e revolve heterogeneidades regionais e diversidades culturais. Portanto, concatenadas, a auto-regulação do mercado e a reprodução ampliada da aquisição capitalista re-ordenam produtivamente a territorialidade brasileira e têm sua contrapartida na aceleração do trânsito de circulação de símbolos, imagens e informações de um modo geral, numa escalada de difusão generalizada, mas intermediada monetariamente, dos bens culturais, dando contornos a uma economia simbólica. A cena das festasespetáculo distribuídas pelas várias regiões é heurística desse processo de implantação de uma estrutura urbano-industrial e de serviços no País e, ainda mais, das ambivalências simbólicas que o mesmo movimento promove no rastro das interpenetrações de matrizes sociossimbólicas.

Se o objeto deste artigo é a combinação institucional entre cultura e entretenimento, considerada articuladamente à expansão da economia simbólica no Brasil contemporâneo, é imperioso levar em conta o encadeamento mais extenso de eventos que se estende no contexto da modernidade. Cultura histórica esta definida também pela interconexão da mercadoria e do valor conferido à exposição, ao fascínio e à satisfação dos afetos pelos objetos ligados à aparência e ao gosto. ${ }^{5}$ Neste sentido, o argumento é o de que a hegemonia alcançada pelas forças sociais que acionam os domínios do entretenimento é compreendida à medida que se considera como tais forças se incorporam à memória e aos modos de transmissão do saber das práticas no mundo cotidiano, às escolhas e aos interesses das pessoas. É decisivo, para os objetivos deste trabalho, levar em conta o modo como os móveis identificados, a um só tempo, aos traços das tradições regionais e da memória da sociedade-nação se engendram mutuamente às instituições do turismo, da comunicação social e da diversão. Engates estes que forjam a natureza do desenvolvimento sociocultural sintetizado na noção de modernização 
cultural e como esta tendência percorre a definição dos lugares de turismo e diversão, no que diz respeito às festas populares. A ênfase desta análise recai na configuração institucional do entretenimento como lugar detentor do monopólio do sentido à expansão controlada das emoções. Zoneamento espaço-temporal este onde festas regionais brasileiras estão redefinidas também como territórios de entretenimento-turismo.

Como assinalado antes, o propósito de retomar o tema da cultura popular no Brasil, à luz das convergências entre economia e cultura, é justamente observar o núcleo de determinados deslocamentos valorativos nas fronteiras entre o que convencionalmente temos denominado global, nacional e local, nos rastros de novas interdependências sociofuncionais. ${ }^{6}$ Com isto, a expectativa de explicitar o quanto o fenômeno do circuito das sociabilidades festivas, ao incidir sobre as distinções entre os níveis culturais, está igualmente na proposta de apresentar a contrapartida analítica composta de novos arranjos e posições na estrutura social, mas igualmente do estabelecimento de emergentes sensibilidades. Creio contracenarem nesses lugares do entretenimento-turismo práticas e símbolos referendados pelas identidades populares regionais com instâncias formais jurídico-institucionais e graus vários de informalidade, mesmo marginais. Além disso, o cálculo empresarial e as práticas lúdicas agrilhoam-se numa composição de tecnologia e tecnoburocracia com artesanato; de elementos herdados da memória colonial com aqueles da dinâmica urbano-industrial e de serviços; de pluralidade étnica e homogeneização cultural; e ainda, de tradicionalidade e estilos de vida orientados pela busca incessante de experiências inebriantes.

\section{Sociabilidades lúdico-artísticas e entretenimento}

Em inúmeras oportunidades, na década de 1990, entre as notícias da seção econômica de jornais de maior repercussão, no País, muitas destacaram a importância crescente dos lucros obtidos com o comércio de atividades artísticas e de diversão alocados em 
grandes festas regionais. Para ilustrar, tomo o seguinte exemplo. Reiteradas vezes o jornalista econômico Joelmir Beting, em sua coluna diária veiculada em diversos jornais espalhados pelo país, se referiu à aproximação entre situações lúdicas e lucratividade. Nos textos, o entretenimento é enaltecido como a "maior indústria do mundo" ou a "maior indústria do terceiro milênio", além de ser definido em seus componentes elementares: "A gastronomia é o eixo da maior indústria do mundo - a do turismo. (...) Entenda-se por turismo o espectro mais amplo do entretenimento, do lazer, da cultura, do esporte, do show biz, dos clubes, dos parques temáticos, dos rodeios, dos eventos, das viagens, das agências, dos operadores - além da hotelaria e da gastronomia." (Caderno de Economia de $O$ Globo, 4 set. 1997). Em uma situação, ao tematizar o entretenimento sob o ponto de vista dos rodeios organizados no interior do Centro-Sul, tendo por epicentro a Festa do Peão Boiadeiro de Barretos (Estado de São Paulo), o jornalista estabelece a comparação, em termos de mercado e faturamento, com o futebol brasileiro e o carnaval carioca:

Barretos está para o calendário dos rodeios como Indianápolis está para o circo da Fórmula Indy ou Wimbledon para o universo do tênis, escreve a revista "Veja" e endossa o "Financial Times". Um milhão e picos de visitantes, em dez dias e dez noites de rodeio e show biz. Vão gastar em Barretos e arredores perto de $\mathrm{R} \$ 150$ milhões. Pois no carnaval do Rio de Janeiro, este ano, a fatura de uma semana, segundo a Embratur, contentou-se com R $\$ 80$ milhões. Sim, maior que o futebol, o rodeio acaba de superar também o carnaval. (...) A televisão ainda não conseguiu passar a dimensão do evento. Também ela não sabe o que está perdendo. Barretos não consegue recepcionar tanta gente. Ela distribui a carga para as cidades da região. Num raio de 150 quilômetros da arena, hotéis, pensões e casas particulares hospedam forasteiros do Brasil e do exterior. Entre outros, esta semana, 143 jornalistas estrangeiros credenciados. (Joelmir Beting, coluna no Caderno de Economia de O Globo, 28 ago. 1997).

Concentrando-se na expectativa de lucro a ser gerado pela "indústria dos rodeios" ainda no festejo em Barretos, também o 
jornal a Gazeta Mercantil ${ }^{7}$ recorreu à semelhança entre ambos os eventos (do interior paulista e o carioca) para acentuar a comparação entre as grandezas monetárias:

O interior paulista é o palco de $85 \%$ de todos os 1,2 mil eventos do gênero (rodeios) realizados anualmente no País. Barretos está para São Paulo assim como o Sambódromo - a passarela dos desfiles carnavalescos das escolas de samba - está para o Rio (de Janeiro). São esperados 1 milhão de pagantes para o megarrodeio, muito mais que as 132 mil que lotariam o sambódromo paulistano em quatro apresentações. A festa de Barretos é o evento mais importante para publicidade da Brahma depois do carnaval. O camarote da cervejaria no megarrodeio só perde em badalação para o 'Camarote $\mathrm{n}^{\circ} 1^{1}$ ', da Marquês de Sapucaí (jornal Gazeta Mercantil, 6 ago.1999).

E o mesmo artifício funciona para enfatizar como os fluxos de públicos, reconhecendo nesses os visitantes turísticos, são decisivos quando se quer medir o "sucesso" de algo no setor do entretenimento:

Só é bem sucedido na indústria do entretenimento - que inclui arte, cultura, esporte e turismo - quem sabe se comunicar. Assim, a festa do Peão Boiadeiro de Barretos pode ser considerada um paradigma de sucesso em todos os segmentos desta indústria, especialmente no turismo, uma vez que leva 1,5 milhão de visitantes para Barretos, cidade de 104 mil habitantes a 428 quilômetros da capital do Estado de São Paulo. De acordo com o Clube Os Independentes, que promove o rodeio há 44 anos, os visitantes deixarão, pelo menos, $\mathrm{R} \$$ 200 milhões em um raio de 150 quilômetros ao redor da cidade, entre os dias 20 e 29 de agosto, período de realização da festa. A estimativa pode ser considerada conservadora, uma vez que dificilmente um visitante gastará apenas a média de R $\$ 130$ entre hospedagem, ingressos, alimentação e compras - trata-se de um público famoso por sua inclinação consumista. (Gazeta Mercantil, 19 ago. 1999)

Nos trechos acima, a apresentação das grandezas monetárias interessa sociologicamente pelo fato marcante de estarem regularmente manifestas as comparações entre diferentes eventos, mas todos perpassados por uma mesma conduta movida pelo sentido da aquisição econômica sob a égide da atitude empresarial. É a princípio adequado concluir: os números revelam a aproximação do zoneamento espaço e temporal do lúdico daquilo que, na tipificação 
da atividade visando satisfazer o "desejo de obtenção de utilidades" a partir da disposição de bens de serviços, Max Weber define como "racionalidade formal" da administração de carências. Afinal predomina como critério a aplicação consciente e planejada de meios, procurando prever calculadamente a otimização dos últimos na perseguição dos fins objetivados. E isto se dá no interior do tipo de empreendimento aquisitivo empresarial, dinamizado pela troca calcada na busca da remuneração monetária e mediante a oferta de serviços demandados (Weber, 1992, p. 62).

Por outro lado, especialistas e autoridades da área cultural chamam a atenção para os inestimáveis préstimos dos chamados patrimônios imateriais para ancorar programas de desenvolvimento humano e social. Em artigo publicado recentemente, também no jornal Gazeta Mercantil, o antropólogo Antônio Augusto Arantes, presidente do Instituto do Patrimônio Histórico e Artístico Nacional (Iphan), vasculha as potencialidades dos "recursos patrimoniais" tendo em vista o uso adequado na promoção do desenvolvimento autosustentado de comunidades locais, quando articuladas a agências externas capacitadas na oferta de auxílio técnico. Para ilustrar o seu argumento, exatamente ele observa o ajuste entre o aumento de investimentos em turismo e o interesse pelas festas populares. Anota o deslocamento das últimas em relação ao insulamento nos limites comunitários originários, no andamento da extensão dos quadros sociais dos lugares, no instante em que estes agregam "principalmente jovens vindos das grandes cidades do País e do exterior, investidores imobiliários, comerciantes e visitantes que retornam a cada estação buscando participar da vida local" (jornal Gazeta Mercantil, 4 out. 2004). A reportagem ressalta, então, as negociações envolvendo "nativos" e "forasteiros" em torno de valores como tradição e inovação no tocante à realização do festejo. No entanto, sublinha estar nos traços diacríticos mais marcantes da continuidade de um modo de ser e viver, logo básicos no delineamento de uma identidade local, o alvo do mercado capitalista empenhado em metamorfosear as diferenças culturais nas atrações promovidas pelo marketing. Igualmente, as políticas públicas, sobretudo aquelas voltadas para os patrimônios, são sensíveis aos mesmos traços. A 
sincronia desses planos teria como resposta, o recurso à reinvenção de tradições por parte da "comunidade", ou seja, os objetos da estima coletiva tornam-se núcleos de exposição da singularidade local, atrativos de públicos externos e anônimos.

Sem dúvida, as palavras do antropólogo iluminam o debate teórico sobre as modulações entre os elementos protocolares do rito e as mudanças socioculturais, no caso aquelas vinculadas ao implemento do comércio de bens simbólicos e serviços de lazer e turismo. A chave categorial da polarização entre "agências externas" e "comunidade", no entanto, contém alguns complicadores para o entendimento do processo enfocado. Primeiro, a idéia de comunidade guarda um sentido de consenso e deixa de considerar as assimetrias internas de poder e status, incidindo seja na emergência de diversidades, seja em hierarquias fundadas em desigualdades na retenção e uso de recursos. Porém, o mais significativo corresponde ao fato de que a topologia estabelecida entre "nativos" e "forasteiro" embaça o olhar a respeito da própria complexidade e diferenciação social constitutivas dos circuitos das festas. Afinal, o "próprio" e o "alheio" são demarcados nas redes de interesses incluindo elos que podem ir dos "festeiros" (administradores e produtores de diversas ordens), às instâncias do poder público nos níveis local, regional e nacional, além dos patrocinadores e agências empresariais prestadoras de serviços de lazer e turismo. ${ }^{8}$

Perseguir tais ajustes é crucial à discussão aqui, mas daremos prioridade à sugestão deixada por Arantes de apreender o engate da oferta de bens afetivo-identitários com as demandas mercantis e as prerrogativas embutidas nas políticas públicas para o setor cultural, no anverso dos programas de desenvolvimento.

A princípio, a compreensão da síntese entre práticas e símbolos lúdico-artísticos populares e economia capitalista, a partir da prestação de serviços de lazer, exige atentar ao processo mesmo de modernização cultural no Brasil. Para isto, a evolução da sistemática 
turística constitui uma fresta pela qual podemos apreender as condições de possibilidade de uma economia simbólica no País. Observado o encadeamento promovido nas últimas décadas, percebe-se que a materialidade turística deu consistência aos nichos das viagens e aos lugares turísticos e estes passaram a corresponder, cada vez mais, a espaços de circulação intensa e densa integração funcional da economia capitalista global, espaços esses demarcados como territórios de fronteiras indefinidas, permeados pelos signos da civilização moderna, por intermédio da materialidade dos seus utensílios e pela regulação das suas instituições cosmopolitas, aninhadas na rede de consumo transnacional. Deste modo, no Brasil, hotéis, shoppingcenters, restaurantes, lanchonetes, aeroportos, aviões, automóveis, marinas, casas de espetáculos e de danças, meios de comunicação eletrônicos, agências de viagem, empresas de transportes, entre outros, ambientam-se às singularidades geográficas e étnico-históricas regionais, na contrapartida do desencaixe destas últimas dos enraizamentos locais, regionais e nacionais. A concatenação descrita está no anverso da fixação do divertimento como valor na pauta de reivindicações e dos orçamentos individuais e coletivos. Tanto os levantamentos estatísticos oficiais quanto aqueles realizados sob encomenda da iniciativa privada incluem a diversão como uma categoria de reconhecimento dos hábitos da população. Mais que isto. Inferências têm sido realizadas para mapear os deslocamentos no comportamento da população e indicar nichos mercadológicos a serem otimizados. Deste modo, o Instituto Brasileiro de Opinião, Pesquisa e Estatísticas (Ibope), num levantamento feito para mapear e mensurar o tamanho do mercado consumidor de diversão e viagens no interior paulista, entre 1999 e o ano 2000, anotou que mais que os cariocas (36\%), embora menos que os paulistanos (50\%), $47 \%$ dos habitantes dessa área viajaram pelo país.

Isto ocorre à medida que o campo institucional do entretenimento ganha concretude no País e no seu interior, as diretrizes das práticas prescrevem a correlação da diversão com as atividades 
empresariais e tem prioridade uma divisão técnica das funções, a qual, por sua vez, favorece a propagação de um ethos profissional entre produtores, administradores e mediadores de bens simbólicos. Deste modo, os diversos mercados de trabalho entrelaçados com este domínio apresentam uma já considerável escala de consumo no conjunto dos ramos. Por exemplo, o valor com as despesas, que em 1988 situava-se em U\$S 13,17 bilhões, alcançou U\$S 20,856 bilhões, em 1994, empregando direta ou indiretamente, nesse mesmo ano, dez milhões de trabalhadores. Distribuindo-se esses números pelas diversas áreas mais diretamente comprometidas com o entretenimento-turismo, obtém-se um quadro, parcial, da base instalada no país. O mercado de refeições coletivas (bares, botequins, lanchonetes, confeitarias, restaurantes, entre outros) abrange um total 1 milhão e 36 mil estabelecimentos, assim distribuídos: 73,4\% no Sudeste, $12,5 \%$ no Sul, o Nordeste com 6,7\%, empregando cinco milhões e quinhentas mil pessoas em 1996. Nesse ano, existia o registro de 9.921 agências de viagens e operadoras, mais da metade situada na região Sudeste, empregando formalmente 93.681 trabalhadores. Finalmente o parque hoteleiro corresponde a 18.026 estabelecimentos, abrigando mais de meio milhão de apartamentos, contando com uma mão-de-obra (especializada ou não) de 287.275 trabalhadores. No plano dos transportes rodoviários, o país contava, em 1993, nas linhas interestaduais, com uma frota de 28.455 ônibus. Enquanto o fluxo de passageiros aeroviários, embarcados e desembarcados, considerando apenas as 29 maiores empresas reconhecidas pelo Infraero, saiu de 3.874.058, em 1990, para 5.320.477, no ano de 1994 (ver Embratur, 1996). As informações arroladas reivindicam atenção à ascendente importância do entretenimento, no geral, para a geração do produto interno bruto do País, fator com incidência sobre a base ocupacional da mão-de-obra, dos investimentos, das trocas ordenadas pelo mercado capitalista e mesmo na pauta de exportações brasileiras, no que concerne ao comércio turístico. 
Porém, o que concluir sobre as repercussões destas alterações materiais em termos normativos e, principalmente, do ponto de vista dos sistemas das práticas culturais? Penso que, primeiro, a economia simbólica se define pela característica mútua que passa a articular ócio e negócio. Os dados acima conspiram a favor da legitimidade das agências e instituições engrenadas com a aquisição econômica de base informacional vinculada às tecnologias de comunicação e aos aportes financeiros e imobiliários, arranjo este decisivo na tendência de rentabilidade do capital, de acordo com as prerrogativas imobiliárias e especulativas do capitalismo "desorganizado" contemporâneo (Lash \& Urry, 1994). ${ }^{9}$ Com isto, tornam-se objetos prioritários tanto o espaço em suas dimensões geográfica e arquitetônica quanto o patrimônio étnico-histórico composto de expressões em que se atualizam memórias coletivas. Por outro lado, a idéia da economia de símbolos e espaços igualmente exorta a admitir a atuação de determinada educação dos sentidos agindo sobre o enquadramento das percepções e estimas em homologia com a categorização dos espaços e seus móveis ajustados aos valores da sociedade de consumidores e ao modo, aí, de atendimento de demandas pelo reconhecimento de estimas de pessoas e grupos. A correlação favorece o desenvolvimento do entretenimento, no instante em que as sociabilidades comprometidas com a estrutura de sentimentos gerada dão primazia ao ethos da distração e, ainda, encontram respaldo na divisão do trabalho e das funções monitorada pela auto-regulação do capital, no ápice da sua dimensão especulativa e da modalização flexível dos modos de aquisição ampliada da riqueza.

Nesse sentido, o estudo desse circuito de festas populares contribui na apreensão do feixe de atividades e processos cuja estabilidade ajuda a emoldurar uma dimensão da experiência social e uma esfera institucional que se consubstancia no segmento de mercado de serviços, notabilizado pelas atividades vinculadas ao entretenimento, campo onde se concertam, em gradações, esquemas de produção e modos de vida formais e informais diversos, mas todos 
girando em torno da legitimidade subjacente ao consumo cultural sob o invólucro da atmosfera do lazer. Ou seja, essa dinâmica economia está implicada num zoneamento espaço-temporal e numa ordem de comportamentos nos quais mesmo o trabalho do lúdico interna-se numa rotina não redutível à da produtividade, mas cujas experiências e atitudes estão conceituadas pelo simultâneo excitamento às sensações e ao estímulo à vontade (criadora); também pelo distanciamento no tocante à busca cautelosa, logo calculista do prazer (Featherstone, 1997, p. 71-78).

Retorno ao plano histórico-empírico. Detenho-me, uma vez mais, no escopo do emaranhado e das estratégias discursivas sintonizando agências e instâncias decisórias, porque ele contribui para a percepção da recriação dos sentidos das festas populares no quadro deste redimensionamento da materialidade e dos quadros de valores no País. Algumas das declarações do então Ministro do Esporte e Turismo do Brasil, Rafael Greca de Macedo, remetem à mesma percepção do enlace com o conjunto de pressões nacionais e transocietais que se vai formando em torno dessas festas. Falando sobre os festejos carnavalescos no Brasil, em 1999, a autoridade acentua a trama de produtores e prestadores de serviços que viabilizam tais acontecimentos e lamenta a ausência de dados oficiais mais precisos a respeito da economia festiva. Lembra, ainda, como eventos dessa natureza "puxam" o turismo e estão alçados numa dimensão transcontinental:

O mundo civilizado e rico sabe disso. As maiores cidades têm gerência de eventos. Veneza retomou seu carnaval barroco a partir de 1983, e suas gôndolas deslizam em rios de dinheiro. Barcelona e toda a Costa do Sol espanhola recomeçaram a marcar mascaradas e desfiles. $\mathrm{Na}$ Itália, a partir do Sul, até Viareggio, o carnaval está voltando a um litoral quase sempre frio e chuvoso, nesta época do ano (jornal O Globo, 12 fev. 1998).

Como que justificando seu cargo e a função que exerce, o ministro manifestara a aparente contradição na continuidade estabelecida entre festa, trabalho e lucro, borrando a fronteira entre o sério e a brincadeira, enfim, o ócio e o negócio: 
Eu, ministro de Esportes e Turismo do Brasil, vou trabalhar no carnaval. Estarei nos desfiles de Olinda, Recife, Salvador, Rio de Janeiro e Florianópolis, exortando nosso país a profissionalizar sua festa máxima. Que tudo seja sempre limpo (não podia esquecer da turma da limpeza), com preços honestos, longe da dolarização. Porque onde tem lixo e carestia não tem turista. Vamos trabalhar, gerar mais emprego no carnaval do ano que vem. (...) Enfim, tudo é carnaval, mas dá um trabalho... (jornal $O$ Globo, 12 fev. 1998).

De um lado, o então ministro exultava ao considerar a pujança dessa economia de símbolos e espaços de um ponto de vista cosmopolita, ao considerar diversos exemplos recolhidos mundo afora; mas, de outro, encontra nas texturas das festas regionais os terrenos mais férteis à prosperidade daquela no Brasil. $\mathrm{O}$ posicionamento da autoridade não se esvai em um vácuo quando vasculhamos alguns dispositivos públicos e privados de financiamento cultural. Por exemplo, realizado durante três noites no final do mês de junho, em comemoração ao ciclo junino na Amazônia, no amplo teatro para mais de 60 mil assistentes, denominado de Bumbódromo, o Festival Folclórico do Boi de Parintins recebe em torno de 200 mil visitantes (do país e do exterior). Com apoio da empresa multinacional de bebidas Coca-Cola, a partir da lei governamental de incentivo, seus custos estão orçados na ordem de US\$ 4,4 milhões gastos com o preparo das apresentações tanto do Caprichoso quanto do Garantido (jornal Gazeta Mercantil, 29 jun. 2001). Estratégia de financiamento recorrente na organização de outros eventos festivos, de ascendente popularidade nacional. Algumas revistas e jornais noticiam a já referida festa do Peão Boiadeiro, sobretudo em razão do rendimento propiciado pela presença de uma média 800 mil a um milhão de pessoas, atraindo em torno de US\$ 3,2 milhões em investimentos privados, os quais representam $50 \%$ do financiamento da festa. Nos dez dias do evento, tendo por centro uma arena especialmente construída para o rodeio, ainda contando com vários palcos onde são apresentados shows de cantores e bandas tanto do gênero típico da região, o sertanejo, quanto de rock. A montagem dessa estrutura e toda a dinâmica do festejo se consolidam como oportunidade de ocupação, já que abre cinco mil vagas de empregos diretos e mais 10 mil indiretos (jornal Gazeta Mercantil, 27 abr. 2004). 
O elevado montante de visitantes que, a cada ano, se deslocam para estes circuitos de sociabilidades festivas estimula a atitude de os empresários tomarem tais ocasiões por alvos de comercialização de produtos nas estratégias de marketing. No período das comemorações a São João nos Estados de Pernambuco e da Paraíba, a montagem da infra-estrutura para os festejos recebe até US\$1,1 milhão em patrocínios, mas a expectativa das companhias é obter um lucro estimado em US\$ 3,7 milhões (jornal Gazeta Mercantil, 14 jun. 2004). ${ }^{10}$ Tais valores são possíveis pelos efeitos da comemoração, envolvendo setores tão distintos da vida regional, ou seja, articula-se ao comércio ambulante, artesãos, varejo formal e trade turístico. $\mathrm{Na}$ cidade pernambucana de Caruaru, por exemplo, no ciclo junino são empregados, ainda que em regime precário, 10 mil pessoas para atuar como ambulantes ou no apoio à realização de 900 shows (jornal Gazeta Mercantil, 10 jun. 2003). A cidade paraibana de Campina Grande, também, oferece alguns dados ilustrativos a esse respeito.

Distante $126 \mathrm{~km}$ da capital João Pessoa, Campina Grande conheceu, nas décadas de 30 e 40, a aceleração do crescimento populacional em parte das regiões do Agreste e do Sertão nordestinos, com os benefícios proporcionados pelo comércio do algodão, já que se situava no centro de um importante pólo de cultivo da planta. Hoje existe um decréscimo na importância desse ramo da economia regional. Ao contrário, os festejos a São João sempre mais ocupam, desde os anos 70, posição destacada tanto na divulgação quanto na economia da cidade e do Estado. Isto, principalmente, após a inauguração do Parque do Povo, que desde 1986 abriga as comemorações juninas. Encarregada da divulgação do evento, a Prefeitura de Campina Grande, através da Secretaria de Turismo, divulga-o como o "Maior São João do Mundo", estratégia de marketing pertinente ao duelo simbólico travado com a cidade pernambucana de Caruaru, pelo título de capital da festa de São João nordestino, brasileiro e "mundial".

Na versão do festejo de 1998, estimou-se que o consumo de cervejas atingiu 600 mil unidades em um mês de programação (5 de junho a 5 de julho), período quando cerca de 60 mil pessoas 
diariamente freqüentaram as dependências do seu pavilhão central, onde havia 300 barracas vendendo bebidas e comidas típicas da região (queijo de coalhoe carne de sol, por exemplo). Compreendendo uma área de 42 mil metros quadrados, o espaço é conhecido como "Forródromo". Aí, no dia 6 de junho daquele ano, a mais famosa paraibana viva, a cantora Elba Ramalho, fez um show para 20 mil pessoas, lançando nacionalmente seu compact disc intitulado Flor da Paraíba, manifestação clara da identidade regional, o que, por seu turno, é compreensível na trajetória da artista. Desfrutando hoje de fama e fortuna ao ser responsável pela atualização, mediante emissoras de rádio FM e pela televisão, nos anos 80, do gênero musical forró - imortalizado pelo cantor Luis Gonzaga, em meio à propagação nacional das ondas do sistema de radiofonia nos anos 40 e 50 -, a cantora ocupou um dos três grandes palcos montados, obedecendo determinada hierarquia. Aquele palco chamado de Pirâmide (em função da solução arquitetônica desenvolvida) comportou atrações musicais consideradas "médias", isto é, cuja popularidade é mais restrita ao sítio local e suas vizinhanças. Outro palco, Ilhas, destinouse ao autêntico "forro pé de serra". Ali a musicalidade ficou por conta dos trios de sanfona, zabumba e triângulo. Já o maior, foi, sugestivamente, nomeado em homenagem ao primeiro radialista de FM de Campina Grande, Arraial Hilton Motta, e comportou as celebridades do porte de Elba Ramalho.

Embora um dos traços distintivos da festa consista na apresentação de grupos folclóricos e, principalmente, no concurso entre os 42 grupos de quadrilhas, em um dos traços distintivos da festa, a Prefeitura resolveu deslocar o folguedo para o centro histórico da cidade. Isto ocorreu no momento em que tal região foi alvo de um conjunto de medidas visando "revitalizá-la". Trata-se, no entanto, da intervenção com vista a redefinir o espaço, considerando os novos imperativos dos serviços de cultura, lazer e diversão. Os esforços de enobrecimento dessa área edificada têm contrapartida no imperativo de preservação da autenticidade cultural dos festejos juninos nativos. Para tanto, a comissão encarregada de organizar (e do julgamento) o concurso de quadrilhas foi taxativa em proibir qualquer estilização 
coreográfica e indumentária, exigindo a manutenção do caráter "rústico" do bailado folclórico.

Ao consistirem nos festejos destacados como cartões postais da tradição cultural brasileira, as folias carnavalescas destacam-se como protagonistas e modelos do processo em que são sincronizados re-significação de memórias lúdico-artísticas populares, trânsitos de símbolos e redefinições de espaço com finalidades de incremento do comércio de lazer e diversão no País ${ }^{11}$ (Farias, 2003, p.190). Para se ter uma idéia, em se tratando do Rio de Janeiro - o principal portão de entrada do País, abrigando mais de $35 \%$ dos visitantes de outros países -, no carnaval do ano 2000, cerca de 300 mil turistas (sendo 200 mil estrangeiros e 100 mil domésticos) visitaram o Rio de Janeiro (Riotur, 2000). Os resultados de um estudo do Ministério do Trabalho sobre o impacto da festa na economia da cidade revelam: algo em torno de US\$ 1 bilhão são proporcionados durante o ano e 300 mil empregos diretos gerados pelos preparativos da festa e sua realização (Ministério do Trabalho, 1999, p. 68-72). Não é de estranhar que, em 1998, os jornais tenham noticiado com alarde o aumento na ocupação da rede hoteleira. Desde 1992, os hotéis do Centro e da Zona Sul onde se concentra a maioria dos estabelecimentos voltados para o setor turístico - não apresentavam uma média de ocupação como naquela temporada carnavalesca, entre $80 \%$ e $98 \%$. As notícias também se referiam aos gastos municipais com a festa terem saltado de R \$ 2,2 milhões para US\$ 3 milhões, destinados aos bailes populares e, sobretudo, à primeira grande reforma do principal palco do carnaval carioca - a passarela dos desfiles das escolas de samba: o Sambódromo - re-capeamento e pintura de 750 metros da pista, e 86 banheiros recuperados. ${ }^{12}$ Davam atenção ao fato de todos os ingressos para os dois dias de desfiles terem sido comercializados com uma semana de antecipação, quando nos anos anteriores às vésperas do evento apenas $70 \%$ haviam sido vendidos. ${ }^{13}$

Ao fim da festa, os mesmos jornais divulgaram os boletins da Associação Brasileira de Agências de Viagem (Abav) e da Associação Brasileira da Indústria Hoteleira (Abih) a respeito da receita total de U\$ 100 milhões, gerados no mesmo período. No ano 
seguinte, mostraram-se mais evidentes as ações do poder público municipal: a Prefeitura voltou-se para a execução de maiores investimentos na festa, afora aqueles já destinados aos desfiles de escolas de samba. Isto se manifestou na tentativa de resgatar o pólo da folia de rua - o centro da cidade - dando-se maior atenção à infra-estrutura, com a melhoria dos serviços: aumento do contingente policial, diversificação das unidades sanitárias, melhoria da iluminação, da sonorização e dos módulos de arquibancadas na Avenida Rio Branco e na Praça da Cinelândia, com seus bailes populares coloridos pelo passeio dos grupos de mascarados (os clóvis) e grupos caricatos, de fantasias originais, ou dos recentemente ressuscitado encontro belicoso entre os blocos de embalo, os tradicionais rivais Cacique de Ramos e Bafo da Onça. No local também foi instalado uma ostensiva decoração aérea, como há mais de dez anos não acontecia, cujos motivos tiveram por tema justamente os cem anos de Carmem Miranda, nome que sintetiza o tropical mito e signo do carnaval e do samba cariocas.

$\mathrm{Na}$ esteira da mesma confluência entre financiamento e folia carnavalesca, agora contando com as informações arroladas por Elizabete Loiola e Paulo Miguez, a capital da Bahia, para assegurar o título de a "maior festa popular do mundo", apresenta números formidáveis desde de 1994. Os três circuitos que constituem a folia carnavalesca em Salvador - Avenida Sete de Setembro, BarraOndina e Pelourinho -, quando somados, abarcam uma extensão contígua de $10 \mathrm{~km}$, além da ocupação de mais nove quilômetros de ruas que lhe são transversais e paralelas. Esse espaço permaneceu ocupado durante 120 horas ininterruptas, em cinco dias, tempo no qual foram realizados 462 shows, para os quais, naquele ano, foram mobilizados três mil artistas, tendo por base 78 trios elétricos (tanto independentes quanto os dos blocos). A platéia chegou, nos momentos mais concorridos, até 1,5 milhão de pessoas, e, entre os $630 \mathrm{mil}$ visitantes, haveria aproximadamente a 64 mil turistas estrangeiros. A multidão distribuída ou nas 161 entidades recreativas, agregando ao todo 150 mil desfilantes, ou nos magotes daqueles que brincaram na "pipoca" - isto é, o folião sem trajes específicos, disposto fora das 
cordas dos blocos. Esta massa utilizou o serviço de mais de 2.061 pontos de venda de comidas e bebidas, sem esquecer dos dois mil vendedores ambulantes. A estrutura incluiu ainda 40 unidades sanitárias, 15 postos de atendimento médico e 20 outros de orientação e atendimento em geral. A segurança contou com um contingente de nove mil policiais; da limpeza encarregaram-se dois mil trabalhadores da Companhia de Limpeza Urbana na coleta de 1.500 toneladas de lixo e a saúde pública dispôs de 330 fiscais, cujo desempenho resultou na inspeção de 2.700 pontos de venda. Finalmente, o serviço de ônibus funcionou 24 horas diariamente (Loiola \& Miguez, 1995, p. 344).

Diante dessas cifras, os autores argumentam consistir a festa, hoje, na maior fonte de renda e emprego para a população de Salvador. Lançando mão de cifras fornecidas pela Empresa de Turismo de Salvador, são em média 120 mil empregos diretos criados no período e negócios orçados em US\$198,8 milhões (Emtursa, 2001). Por isso, ambos se referem à "economia" e à "indústria" do carnaval, delimitando o período que se estende da segunda metade dos anos 80 ao início da presente década como aquele em que são definidos os contornos de "megaevento", atualmente característico da festa, o momento em que as "possibilidades de negócios ampliam-se pari passu com a complexificação da estrutura organizacional dos atores. O carnaval passou a ser visto como um negócio estratégico pelos arranjos institucionais públicos e privados que se desenvolvem em seu entorno" (Loila \& Miguez, 1995). Em nome das respectivas estratégias de marketing para conquistar clientes, mas visando, igualmente, às inserções na programação da televisão e à ocupação de painéis publicitários espalhados pelos espaços da festa, além da possibilidade de ocupar com suas respectivas marcas as laterais dos trio-elétricos, é acirrada a concorrência entre bancos, cervejarias, operadoras do setor de comunicação, montadoras de automóveis, entre outras, para vencer os editais lançados pela prefeitura municipal.

Nota-se que, conjugadas por um leque de mediações ao íntimo da rede de consumo de bens culturais e serviços de entretenimento e 
lazer, é possível concluir estarem muitas das festas populares regionais não apenas integradas no grande processo de modernização e reordenação societária, mas também se impõem como parte da complexidade social. Isto, ao serem redefinidas enquanto espaços de fluxos, para além dos lugares plenos da delimitação das convivências ordenadas pela tradição comunal. Há, aí, um duplo aspecto. De um lado, estão diferenciadas no interior da esfera cultural, na qual interagem tradições seculares (discursivamente) classificadas enquanto folclóricas, de acordo com os conceitos que definem o quadro dos patrimônios nacionais, com uma tradição própria do entretenimento. Já esta última tem por característica marcante os apelos calculados aos sentidos mediante os arranjos audiovisuais construídos como ambiências do lazer como diversão. De outro, o entrecruzar das memórias lúdico-artísticas populares mostra-se soldado no concerto social que tem um dos seus mais decisivos pilares, ao lado do mercado capitalista, na força política, econômica e ideológica das instâncias privadas que contingenciam a circulação monetarizada da cultura e os agenciamentos de prazer.

A Economia de símbolos e espaços diz respeito, logo, à maneira tal qual na sociedade de consumidores o entretenimento se define como um mecanismo de consagração e instância de legitimidade das práticas culturais. Como observa Renato Ortiz (1999, p. 170-171), a mediação do mercado cultural se tornou incontornável, agregando ou excluindo mediante o crivo das práticas norteadas pela ética hedonista do consumo com sua ênfase nas permutas de significados. Integrados nessa rede, os símbolos populares das festas regionais compartilham da economia de signos e espaços, justamente ao compor tanto o cenário quanto o tráfego intenso de significados que deixam entrever o ambiente da globalidade, com sua propensão para articular cultura e dimensão financeira e especulativa do capital. Tanto que o lazer irá integrar um dos ramos dos negócios do capitalismo, o mais sofisticado, aquele das atividades de serviços; aí se articulam o comércio de habilidades e conhecimentos com os suportes materiais mais distintos (Heller \& Feher, 1998, p. 29-67 e 204). 


\section{Considerações finais}

No decorrer do último século, certas vertentes marxistas e funcionalistas das teorias da modernização igualmente ressoaram na compreensão da cultura popular. Embebidas do primado racionalista do Iluminismo, com sua atitude desdenhosa quanto ao passado, entendendo-o como fonte da ignorância perpetuada pelas instituições do Antigo Regime, as teorias da modernização galgaram prestígio à maneira de fórmulas de compreensão e entendimento da vasta realidade instaurada com a intensificação das dependências planetárias. Assim, muitos intérpretes concluíram o desenvolvimento sócio-humano segundo os ditames de um evolucionismo substancial ou formal. As categorizações, oscilando entre modernidade ou tradição de situações específicas, foram, logo, acionadas no rastro de concepções teleológicas e lineares do tempo, portadoras de intensa carga normativa, ancorada na crença sobre um futuro que se elucidaria no estágio secular industrial-científico. Adepto da revisão deste ponto de vista, o sociólogo Anthony Giddens desenvolve uma convincente argumentação sobre o lugar re-significado da tradição no escopo dos contextos de modernização reflexiva. $\mathrm{O}$ autor enxerga na disseminação sem precedentes das instituições da modernidade o reverso da medalha da radicalização dos predicados modernos tal como se dão os "processos de mudança intencional". Conclui ele que tal virada atingiria a tradição como núcleo de formulação de verdades compactadas na memória coletiva, mas repassada criativamente no decurso geracional, graças à vivacidade dos ritos $\mathrm{e}$ hábitos galvanizados por uma narrativa instaurada num passado exemplar. A dissolução dar-se-ia na esteira da propensão a problematizar a tradição, ou seja, a tradição seria descolada da recursividade institucional e pessoal cotidiana, até levar ao seu abandono, justamente ao se desacreditar o controle ritual do tempo pela repetição de uma narrativa exemplar (Giddens, 2001, p. 36-47).

O sociólogo britânico oferece, porém, tão parcos quanto insatisfatórios elementos empíricos para garantir rigor quando assevera um generalizado recuo das tradições, que seria motivado pelas pressões que tornam a abertura e a reflexividade fatores 
decisivos na orientação das pessoas. Insiste ele na tese de que no "presente" sobrara apenas a "indústria das heranças", já que a tradição se teria restringido ao espetáculo da lembrança despossuída da "seixa" proporcionada pela experiência cotidiana (Giddens, 2000, p. 54). Contudo, até que ponto o generalizado recuo das tradições seria motivado pelas pressões que tornam a abertura e a reflexividade fatores decisivos na orientação das pessoas no cotidiano contemporâneo? Talvez a vida em uma sociedade "pós-tradicional" também possa implicar a re-significação dos repertórios de estilos abrigados pela aura de tradição, considerando para isto a situação na qual os trânsitos intensificados de pessoas, idéias e tecnologias dão impulso à operacionalização de lembranças mediante a dinâmica de riscos motivada pela dificuldade de calcular o futuro devido à socialização generalizada. Condição em que muitos entre os agentes se empenham em re-apropriar e monitorar as condições ambientes, utilizando-se tanto dos influxos de elaborações dos especialistas quanto do recurso a outros fundos de conhecimentos intergeracionalmente produzidos. Não se trata, portanto, de falar em tradicionalismos empenhados em recriar o passado pelo presente, mas da maneira como determinados estilos são remanejados e, mais que resíduos, passam a constar do panorama do atual, compondo as problematizações que ganham relevância nas práticas e sentimentos.

À luz das contingências estruturais deflagradas ao longo do século XX, eu considero que processos de mudança embasados no empenho em re-apropriar as condições ambientes propiciaram o remanejamento dos repertórios de símbolos das tradições referidas aos sistemas das práticas lúdico-artísticas populares no Brasil. Redefinições ocorridas principalmente no compasso da coordenação destes últimos por mecanismos vinculados a instâncias diferenciadas de produção e circulação de bens culturais e de diversão, na escalada ascendente do ramo dos serviços de lazer e turismo. Segundo uma dinâmica de conservação e transformação, as trajetórias das festas populares brasileiras catalisam lembranças culturais enraizadas nas experiências dispostas, simultaneamente, na formação de nichos comunitários ambientados em mapeamentos locais e regionais, mas também das narrativas nacionais. Sabemos estarem diferenciadas 
as inserções nestes domínios de memórias. Afinal, ao lado de facções dominantes, estão incluídas experiências de grupos sociais subalternizados, os quais conheceram o estigma étnico-racial e estiveram pressionados a deslocar sua intimidade para o espaço público, em respeito à normatividade do Estado-nação. Mas os entrecruzamentos com as linhas de ação situadas na esfera cultural, no que tange ao acento depositado na conduta estética voltada para a diversão e o peso adquirido pela categoria de popular nos discursos voltados à edificação do patrimônio nacional, deliberaram a favor da concentração dessas matrizes populares nas temporalidades do ócio. Espaços que estiveram crescentemente recobertos pela ritualização da diversão, no decorrer do último século, aproximando-as dos roteiros do entretenimento e turismo, mas contracenando também com as prerrogativas das instâncias da comunicação social em escala ampliada (Farias, 2003, p.13-14).

Por outro lado, é inevitável interrogar até aonde as mesmas práticas investidas das prerrogativas da re-tradicionalização fazem dueto com uma economia simbólica gerida em consonância com os critérios atuais da rentabilidade do capital. E, nesse sentido, seriam reveladoras de alterações nos mundos sociais em que as idéias de narrativa, identidade e memória passam a, cada vez mais, estarem sintonizadas com esquemas financeiro-monetários e integrarem agendas de modernização vinculadas, sobretudo, ao setor de serviços. Mas igualmente confluindo para novas acomodações da compreensão social, desde agora tornando viável a conexão entre culturas e agendas de desenvolvimento econômico ancoradas na lógica da ampliação remunerada do capital. Ora, ao longo deste artigo estive chamando a atenção para dois aspectos com impactos sobre a compreensão do engate cultura e economia, no Brasil contemporâneo. O primeiro corresponde à interpenetração entre a racionalidade formal dos meios, somada à estratégia simbólica do espetáculo, fundada sobre o efeito bombástico da aparência, com o que discursivamente foi definido como as alteridades possíveis: selvagens, folclóricos e popularcoloniais. Exatamente o segundo aspecto ganha nitidez se considerarmos que, na esteira da ocidentalização, básica à formação 
da sociedade nacional brasileira, tanto o arregimento de símbolos para o plano da cultura quanto o ideário do prazer estético definiram a qualidade de muitas práticas significantes identificadas às populações subalternas. E estas ascenderam, por sua natureza lúdico-artística, a ícones da tradição do povo-nação do Brasil.

Diante da conexão de um e outro aspecto, é possível sugerir como o entretenimento tem sido decisivo, no curso do último século, para distinguir agências, estratégias de comunicação e coalescências intra e intersocietais, conformando uma dinâmica de estilização e pacificação, ampliando toda uma linha de ação. Podemos supor, ainda, que tal conjugação concede os insumos ao tipo de legitimidade mobilizada por muitas das ações reconhecidas enquanto culturais na posteridade dos processos sociais e civilizadores modernos, atuando no remanejamento de posturas e sensibilidades, mas, também, contribuindo para a constituição de referências identitárias capacitadas a percorrer tão diverso leque de grupos e artefatos simbólicos. E porque o dueto entre práticas lúdico-artísticas populares e entretenimento vaza imaginários a respeito de lugares e regiões ou mesmo da nação, diria que é habilitado para contribuir na tessitura de pertencimentos e modos de viver, na justa proporção em que absorve teor nas muitas atitudes anônimas. Poderia concluir que, a despeito do que vaticinou uma sociologia de inspiração desenvolvimentistas, nestas experiências, tradição e moderno ou local, nacional e global resolvem-se em fórmulas, esquemas de classificação e produtos que pavimentam dispositivos de regulação das expressões humanas pautados na centralidade do consumo de diversão.

Talvez as trilhas da conjunção entre práticas lúdico-artísticas populares, entretenimento e economia simbólica nos levam a pensar as modernizações enquanto movimentos marcados pelos entrecruzamentos nos quais se dá o incremento na reflexão tanto sobre as origens quanto a respeito das fronteiras e, com isto, a recriação de símbolos e a exclusão de memórias são cúmplices simultaneamente acionados. Exercícios reflexivos que são ensejados no mesmo substrato envolvendo serviços diversos, finanças, setores produtivos, esquema de comunicação e informação, facções do poder 
estatal no encadeamento de atividades com ingerência no mundo do lazer e do trabalho, da dimensão política, mas igualmente da vida íntima. Sempre tendo em mente que as estruturas deste concerto só resultam efetivas no modo como os elementos étnico-históricos específicos são capacitados e disponibilizados para diferenciar situações, no seu estilo de realizar a modernidade em escala global. Isto é, contribuem na demarcação de espaços privilegiados de experiência da função do divertir, obedecendo ao padrão "civilizado" do relaxamento e do êxtase.

Ainda carece de maior atenção a formação dos monopólios dos artefatos de controle das emoções, por parte de determinados grupos institucionalizados na amplamente diferenciada teia das relações sociais. Tanto do ponto de vista teórico quanto político, as implicações deste tema revelam no espaço de visibilidade do campo concorrencial do entretenimento as reciprocidades e contradições geradas no encontro dos complexos mercantis da cultura e comunicação com os interesses políticos e ideológicos dos ordenamentos estatais de poder. Os meios e pressões às resignificações de lembranças étnico-históricas estão, portanto, articuladas à heterogeneidade de agentes cujas estimas são direta ou indiretamente vinculadas ao comércio de informações, para isto, tendo em conta como as intertextualidades (literário-poéticas, científicas e turísticas) e o perfil assumido pelas práticas que as viabilizam redimensionam memórias e as situam em formatos apropriados à exposição de sentimentos pessoais. Parece ser urgente entender tal formação e sob quais critérios afetos e rentabilidade do capital se tornam recíprocos e também as contradições geradas. Afinal, é a partir desta economia que se dá o comércio das emoções e a transferência para os espaços de visibilidade pública das manifestações moderadas das pulsões humanas, nas territorialidades do entretenimento. No reverso da mesma medalha, estão as festividades de significação étnica e regional e nacional cada vez mais integradas como peças de diversão nos circuitos do lúdicoartístico ancorados no mercado e seus agentes orientadas pelas premissas do encaixamento turístico das expressões referidas no interior do gênero festa-espetáculo. A exemplo do carnaval do Rio 
de Janeiro, as folias carnavalescas e o ciclo comemorativo a São João, ambos no Nordeste, e o Festival Folclórico do Boi-Bumbá de Parintins, na Amazônia.

\section{Notas}

1 Não demorou e a "epopéia" inspirou um novo samba. Também gravado por Beth Carvalho, mas agora assinado por Arlindo Cruz, Almir Guineto, Sombrinha e Mazinho Xerife, em 1998 foi lançado Samba de Marte, com a seguinte letra: "Onde cheguei/ Nenhum mortal chegou/ Modéstia à parte/ Nessa arte, Deus me consagrou/ O meu canto ecoou por todo o universo/ Até em Marte, o meu samba fez sucesso/ Meu samba não cai/ Meu samba é raiz/Coisinha do pai que alegra o país/ Meu samba é legal e o povo adora/ levanta o astral pelo mundo afora/ Foi bonito de se ver o meu pagode espacial/ Abalou e acordou o robô no maior carnaval/ O meu samba de couro, de corda e amor/ Decolou do fundo de quintal/ Abalou e acordou o robô no maior carnaval/O meu samba foi pro espaço/ Mas foi ao espaço e chegou na moral/ Abalou e acordou o robô no maior carnaval/ O meu samba é raiz, pé no chão/ Uma constelação que não existe igual (imortal) (...) Meu samba é melodia e letra/ Planeta e cometa/ Estação orbital (sideral)...”. Aliás, vale lembrar que, já 1985, o desfile carnavalesco da escola de samba Mocidade Independente de Padre Miguel retratou um carnaval sideral no qual cada um dos astros do sistema solar incorporou um folguedo da cultura popular brasileira (ver Farias, 2003).

2 Para o antropólogo Roberto da Matta, um sistema social como o brasileiro - de ausência da hegemonia ideológica exercida por uma única grade classificatória, pois haveria múltiplos códigos referidos a esferas de ação igualmente específicas ("rua", "casa" e "outro mundo", nos termos do autor) -, está na contrapartida da importância adquirida pela lógica relacional e dá ênfase às mediações entre as diferentes éticas dispostas lado a lado na orientação cotidiana da vida. A validade de ambos os mecanismos estaria centrada na possibilidade de conferir coesão a partir de uma condição de tamanha segmentação e discrepância entre espaços e temporalidades. Exatamente por isto, reconhece no "complexo sistema de festas" um modo do qual se dotou a própria sociedade nacional para resolver o problema da coerência sistêmica, na medida em que se justapõem o "tempo linear" da rua com o "tempo cíclico" da casa e, ainda, a eternidade do outro mundo. Far-se-ia viável, sob a égide das festas, a ocasião para ecumenicamente "ligar" tais âmbitos cindidos, 
capacitando-os a formar "um todo coeso e sem divisões" (Matta, 1985, p.130-131).

3 O tratamento valorativo enquanto "moderno" e/ou "tradicional" às práticas populares permanece uma questão ainda candente no interior dos estudos socioculturais, principalmente na América Latina. Por ocasião da II Reunião Interamericana sobre Cultura Popular e Tradicional, realizada em Caracas, na Venezuela, em 1987, o tema em pauta girou em torno da "crise taxonômica" dos estudos sobre folclore (Segato, 1992). Naquele momento, o antropólogo argentino Néstor García Canclini investe contra a distinção entre folclore e cultura popular, exatamente observando a importância adquirida pela cultura popular urbana no continente, na esteira da expansão dos conglomerados metropolitanos. A atenção a essa última tanto descortinava o cenário heterogêneo da produção quanto os circuitos híbridos compostos a partir dos entrecruzamentos do artesanato e das festas populares com a comunicação de massa e o turismo. Desta maneira, ele propõe uma conceituação sintonizada com a representatividade dos produtos por revelar os modos de vida de seus artífices, e não devido a algum estatuto de pureza (Canclini, 1987, p. 9; Cavalcanti, 2004).

4 De acordo com a aspiração de totalidade e autenticidade presente nesta corrente interpretativa, as práticas da cultura popular sobressaem devido ao primado orgânico, ou seja, estariam neles ausentes alguns dos traços destacados da civilização: o conflito, a fragmentação e a incoerência. Por isto, com a "retórica da perda" (Gonçalves, 1997, p.60-61) vigente nas apreciações, lamenta-se e reclama-se da interferência corrosiva do presente sobre tais reminiscências da tradição. Exemplo a respeito, a Carta do Folclore Americano, assinada também em Caracas, no ano de 1970, no rastro da sua congênere brasileira (de 1951), teve por objetivo resgatar e conservar todo o patrimônio constituído pelos "valores tradicionais", entendidos como fundamentos da identidade dos vários povos da região. $\mathrm{O}$ empenho preservacionista manifesta a preocupação com os perigos representados pela industrialização e o impacto das indústrias culturais associadas à cultura de massa (Carvalho, 1991, p. 6).

5 Explorando o tema dos entorpecentes em Baudelaire, mas atento à naturalização da mercadoria no cotidiano da cidade metrópole, Walter Benjamin supõe o valor-de-troca como a alma secular da modernidade, onde a operação mimética do subjetivo se projeta em busca de objetivação na forma-valor, ou melhor, o de "valor-de-exposição" (Benjamin, 1989, p. 52-53). 
6 Embora trate do tipo de arte que encontra em certa região da África, Norbert Elias (1995, p. 47) chama a atenção para as implicações das dependências mútuas sobre o teor e perfil das expressões humanas: "Por outro lado, tal mudança na relação entre produtores e consumidores de arte não está, de modo algum, estritamente ligada à sequiência particular de acontecimentos da Europa. Pode-se ver, por exemplo, uma mudança em direção semelhante na alteração que sofre a arte artesanal das tribos africanas, ao alcançarem elas um estágio superior de integração em que as unidades tribais prévias se fundem em unidades de estado. Também aqui a produção artesanal - por exemplo, de uma figura ancestral ou de uma máscara - lentamente se livra da dependência de um comprador específico ou de uma ocasião específica numa aldeia, e passa para a produção dirigida a um mercado de indivíduos anônimos, tal como o mercado de turistas ou o mercado internacional de arte mediado por comerciantes".

7 O recurso por diversas oportunidades a matérias deste jornal, tomandoas por fonte, justifica-se por ser este veículo aquele de maior repercussão na opinião do setor empresarial no país, tendo suas páginas permanentemente freqüentadas por membros não apenas das elites econômicas, como também políticas e culturais.

8 A fala do presidente do órgão nacional guardião dos patrimônios históricos e culturais é também parte interessada e importante na promoção de condutas favoráveis à "reinvenção de tradições". Isto se forem postas em relevo tanto as intervenções do poder público, promovidas no âmbito "comunitário" mediante os seus órgãos especializados, assim como a ação de técnicos, à maneira dos antropólogos, cuja presença ressoa principalmente no quadro taxonômico compartilhado pelos grupos envolvidos com as práticas e símbolos distinguidos, contribuindo decididamente nas operações de tradicionalização e re-tradicionalização (Farias, 2004, p. 146-56).

9 Como adverte José Carlos Braga, desde a década de 60, são delineados os traços fisionômicos desta economia simbólica, já que se acentua a dinâmica financeira como padrão sistêmico de riqueza do capitalismo. Mas o economista lembra que a rotação vem ocorrendo desde a segunda metade do século XIX, momento em que se desenvolveu a "dimensão financeira autonomizada das corporações". Porque daí em diante instaura-se aquela modalidade de mercado de investimentos no qual títulos representativos das propriedades transitam e são valorados em circuitos específicos, não tendo o compromisso de adequar-se à valorização ativada na esfera produtiva. Tal movimento traz em si os 
elementos que fazem da riqueza imobiliária o padrão dominante às exigências de elasticidade, mobilidade e flexibilidade como próprias ao capital, na gestão e organização social da produção e da distribuição. Na medida em que porta a substituição de um ethos centrado na conduta frugal e laboriosa por outro caracterizado pela especulação, Braga enxerga no curso desses episódios o manifestar da "passagem de um sistema capitalista em que a riqueza era associada à terra, máquinas, equipamentos, edificações, para uma 'nova era', em que a riqueza irá assumindo crescentemente uma dimensão simbólica, na moeda fiduciária e nos ativos financeiros em geral.” (Braga, 1997, p. 212-213).

10 Pelo mesmo motivo, o governo do Estado do Maranhão investiu US\$ 750 mil na com uma agressiva campanha de divulgação da festa junina na capital São Luís, cujas imagens veiculadas em várias mídias destacam o cenário lúdico-popular dos arraiás onde se desenvolvem as danças folclóricas, principalmente a alegria dos brincantes dos boi-bumbás (jornal Gazeta Mercantil, 19 abr. 2004). Ilustrativa de igual tendência, a procissão do Círio de Nossa Senhora de Nazaré, que durante o mês de outubro percorre as ruas centrais de Belém, capital do Estado do Pára, chega a receber 40 mil turistas e injeta US $\$ 7,7$ milhões na economia local (Boletim do Dieese, 2003).

11 Diante de semelhantes aspectos na contemporânea experiência espanhola, o antropólogo Antonio Ariño assinala o redimensionamento das festas populares na modernidade avançada. Nota ele que nesses eventos: “(...) lo cierto es que no podemos dejar de considerar su imbricación con otras categorías de acción coletiva, como espectáculos, atracciones, juegos, ceremonias o festivales." (Ariño, 1996, p.13-14).

12 Aliás, a própria Liga Independente das Escolas de Samba (LIESA), sócia da Prefeitura carioca na organização dos desfiles no Sambódromo, faz questão do reconhecimento do evento no Sambódromo: "O desfile das Escolas de Samba do Grupo Especial assume, a cada ano, grau de importância maior para a vida da cidade e do país. Vira o século como a principal festa do calendário turístico do Rio de Janeiro e como porta de entrada para o visitante estrangeiro que daqui se dirige a outros pontos do Brasil. (...) Cresce, também, nossa responsabilidade em produzir um espetáculo das mesmas dimensões da expectativa que o envolve. Com o apoio e a credibilidade depositados pela Prefeitura da Cidade do Rio de Janeiro e pela Riotur, essa missão tem sido extremamente gratificante. Têm-nos ajudado a aperfeiçoar cada detalhe da organização, elevando o potencial artístico do evento e oferecendo maiores conforto e segurança ao público do Sambódromo. Assim, ajudamos o Rio de Janeiro a ficar mais bonito, alegre e envolvente. Pelos séculos e séculos." 
13 O sucesso na venda dos ingressos para o evento no Sambódromo é também o resultado da transmissão televisual que, além da praça brasileira, chega a outros 60 países por intermédio da Rede Globo. A mesma visibilidade na mídia televisiva faculta aos organizadores do evento lançar mão da estratégia de publicidade que permite o acesso ao financiamento de grandes companhias do setor de bebidas, telefonia e automóveis. Na mesma direção, as escolas de samba optam por muitas fórmulas de financiamentos, oriundos seja de cidades ou Estados do País, seja de empresas, como a Companhia Vale do Rio Doce, que investem com o propósito de ver as suas respectivas histórias e paisagens representadas em músicas, indumentárias e cenários.

Abstract: Economy and culture of the Brazilian popular festivities

The purpose of this article is to highlight some aspects that now characterize the convergence of the culture and the economy of symbols and spaces from the setting of a circuit of large festivals crossing different Brazilian regions. It is observed how the pattern of this circuit of events creates a broader portrait of the establishment of the service and urban-industrial social structure, within which leisure and entertainment interfere with the level of values and expressions, with effects on the resignification of the realms of memory. On the other hand, it is also considered how those symbolic changes are fundamental to the very dynamics of the business of entertainment goods, in the sense that they articulate affection, endearment and life styles with the schemes of capital rentability.

Key-words: popular festivities, economy of symbols and spaces, ludic and artistic practices.

\section{Referências bibliográficas}

ARANTES, Antônio Augusto. Horizontes do patrimônio cultural. Gazeta Mercantil, 4 out. 2004.

ARIÑO, Antonio. La utopia de Dionisos: sobre las transformaciones de la fiesta en la modernidad avanzada. Revista Antropologia, n. 11, marzo, 1996. 
BAUDRILLARD, Jean. A sociedade de consumo. Lisboa: Edições-70, 1979.

BENJAMIN, Walter. Paris no Segundo Império. In: Obras escolhidas. São Paulo: Brasiliense, 1979. v. 3.

BRAGA, José Carlos S. Financeirização global: o padrão sistêmico de riqueza do capitalismo contemporâneo. In: TAVARES, Maria da Conceição (Org.). Poder e dinheiro: uma economia política da globalização. Petrópolis, RJ: Vozes, 1997.

CANCLINI, Néstor García. As culturas populares no capitalismo. São Paulo: Brasiliense, 1983.

La Carta del Folklore Americano y la Politica Cultural en los 80. Trabalho apresentado na II Reunión Interamericana sobre Cultura Popular y Tradicional, Caracas, 1987.

CARVALHO, José Jorge. As duas faces da tradição: o clássico e o popular na modernidade latino-americana. Brasília: Programa de PósGraduação em Antropologia-UnB, 1991. (Série Antropológica, n. 109).

CARVALHO, Rita Laura Segato de. A antropologia e a crise taxonômica da cultura popular. In: SEMINÁRIO FOLCLORE E CULTURA POPULAR: AS VÁRIAS FACES DE UM DEBATE. [Anais]. Rio de Janeiro: Instituto Nacional do Folclore, Coordenadoria de Estudos e Pesquias, IBAC, 1992.

CAVALCANTI, Maria Laura Viveiros de Castro. Cultura popular e sensibilidade romântica: as danças dramáticas de Mário de Andrade. Revista Brasileira de Ciências Sociais, v. 19, n. 54, fev. 2004.

CASCUDO, Luis da Câmara. Dicionário do Folclore Brasileiro. São Paulo: Global, 2000.

CASTELLS, Manuel. The net and the self. In: SUSSER, Ida (Org.). Anthropological perspectives on the informational society. Critique of Anthropology, v. 16, 1996.

CÔRTES, Gustavo Pereira. Dança, Brasil: festas e danças populares. Belo Horizonte: Leitura, 2000.

DREIFUSS, René Armand. A época das perplexidades (mundialização, globalização e planetarização: novos desafios). 2. ed. Petrópolis (RJ): Vozes, 1996.

DUARTE, Luis Fernando Dias. A pulsão romântica e as ciências humanas no Ocidente. Revista Brasileira de Ciências Sociais, v. 19, n. 55, jun. 2004. 
DUVIGNAUD, Jean. Festas e civilizações. Fortaleza: Edições Univ. Fed. Ceará, Rio de Janeiro: Tempo Brasileiro, 1983.

ELIAS, Norbert. Mozart, Sociologia de um gênio. Rio de Janeiro: Jorge Zahar, 1995.

FARIA, Vilmar. Cinqüenta anos de urbanização no Brasil (tendências e perspectivas). São Paulo: Cebrap, 1991. (Novos Estudos Cebrap, n. 29).

FARIAS, Edson. Ócio e negócio: festas populares e entretenimento-turismo no Brasil. Campinas, 2001. Tese (Doutorado) - IFCH-Unicamp.

. Carnaval carioca: a matriz do negócio do ócio brasileiro. Cadernos CRH, n. 38, jun./jul. 2003.

. (Re)tradicionalização ou (re)significações de tradições? In: TEIXEIRA, João Gabriel L. C.; GARCIA, Marcus Vinicius Carvalho; GUSMÃO, Rita (Orgs.). Patrimônio imaterial, performance cultural $e$ (re)tradicionalização. Brasília: ICS-UNB, 2004.

FEATHERSTONE, Mike. O desmanche da cultura (globalização, pósmodernismo e identidade). São Paulo: Nobel, 1997.

GIDDENS, Anthony. Mundo em descontrole: o que a globalização está fazendo de nós. Rio de Janeiro: Record, 2000.

. Em defesa da Sociologia: ensaios, interpretações e tréplicas. São Paulo: Unesp, 2001.

GONÇALVES, Reginaldo. A retórica da perda. Rio de Janeiro: Ed. UFRJ, 1997.

HELLER, Agnes; FEHÉR, Ferenc. A condição política pós-moderna. Rio de Janeiro: Civilização Brasileira, 1998.

HERMET, Guy. Cultura e desenvolvimento. Petrópolis (RJ): Vozes, 2002.

LASH, Scott; URRY, John. Economies of signs and space. London: Sage, 1994.

MATTA, Roberto da. A casa e a rua. São Paulo: Brasiliense, 1985.

ORTIZ, Renato. Um outro território. São Paulo: Olho d'Água, 1999.

POCHMANN, Márcio. O Excedente de mão-de-obra no município de São Paulo. In: JAKBSEN, Kjeld; MARTINS, Renato; DOMBROWSKI, Osmir (Orgs.). Mapa do trabalho informal: perfil socioeconômico dos trabalhadores informais na cidade de São Paulo. São Paulo: Fundação Perseu Abramo, 2000. 
RODRIGUES, Ana Maria. Samba negro, espoliação branca. São Paulo: Hucitec, 1984.

SANTOS, Milton. A urbanização brasileira. São Paulo: Hucitec, 1993.

TINHORÃO, José Ramos. As festas no Brasil Colonial. São Paulo: Editora $34,2000$.

. Cultura popular: temas em debate. São Paulo: Editora 34, 2001.

WEBER, Max. Economia e sociedade. Brasília (DF): UnB, 1992. v. 1. 